\title{
SHENSHI 紳士 ATAU GENTRY CINA: SEKILAS SEJARAH DAN PROFIL KAUM ARISTOKRAT CINA PADA ZAMAN KEKAISARAN ${ }^{1}$
}

\author{
Adrianus L.G. Waworuntu
}

\begin{abstract}
Abstrak
Untuk memahami historiografi yang dikaitkan dengan berbagai aspek sosial budaya di Cina tradisional, adalah sangat penting untuk mengenal terlebih dahulu siapa para pelaku utamanya. Dalam masyarakat tradisional Cina, ada sebuah kelompok yang dikenal dengan kaum gentry Cina, atau dalam bahasa Mandarin disebut shenshi 紳士. Mereka dikenal sebagai kaum sarjana-birokrat Cina yang sehari-hari menjalankan roda pemerintahan pada dinasti-dinasti di Cina sejak duaribu tahunan yang lalu sampai berakhirnya sistem dinasti pada tahun 1911. Kaum gentry Cina ini berasal dari kaum cendikiawan yang menduduki jabatan-jabatan mereka melalui sebuah sistem pendidikan tertentu yang sifatnya terbuka, yang bisa diikuti oleh setiap orang dari strata mana pun dalam masyarakat tradisional. Namun, kedudukan dan gelar yang mereka peroleh ini tidak dapat diwariskan kepada keturunannya. Dari kaum gentry ini muncul para menteri, gubernur, bupati, kaum cendikiawan, sastrawan, serta pemimpin-pemimpin informal baik di tingkat pusat maupun lokal. Sejarah Cina jaman kedinastian diwarnai oleh peran dan tindakan dari kaum gentry ini dalam hampir semua faset kehidupan masyarakat tradisional Cina.
\end{abstract}

Kata kunci

Gentry Cina, sarjana-birokrat, masyarakat Cina tradisional

\begin{abstract}
In order to comprehend the many aspects of social and cultural historiography of traditional China, it is imperative to recognize who are the main actors. In traditional Chinese society, there is a significant category known as the Chinese gentry, or the shenshi 紳士 in Mandarin. They were known as the Chinese scholar-official class who administered the traditional Chinese dynastic government system since more than two-thousand years ago until the abolishment of the system in 1911. The Chinese gentry emerged from the intellectuals who became officials by going through a special, open-recruited, educational system; a system that enabled every person from any strata in traditional society to enroll. However, their office and titles could not be passed to their offspring through birthright. All ministers, governors, magistrates, intellectuals, poets, men of letters, and also the metropolitan and local informal leaders emerged from this class. Chinese histories in the times of the various dynasties are decorated by the roles and actions of this shenshi.
\end{abstract}

\section{Keywords}

Chinese gentry, scholar-official, traditional Chinese society,

\footnotetext{
1 Makalah ini pernah disampaikan dalam Kuliah Umum Program Studi Cina, Fakultas Ilmu Pengetahuan Budaya, Universitas Indonesia pada tanggal 7 Maret 2012.
} 


\section{PENGANTAR}

Negeri dan masyarakat Cina telah dikenal dan diketahui memiliki sejarah yang panjang dan sangat dinamis. Bahkan kekaisaran Cina sebagai sebuah bentuk pemerintahan politik yang diwariskan secara estafet dalam sistem kedinastian nyaris tanpa putus, dan dapat dikatakan adalah yang paling panjang dalam sejarah umat manusia. Tidak mengherankan jika kebudayaan Cina juga kemudian dikenal sebagai sebuah kebudayaan yang tinggi yang berkembang secara dinamis sejak ribuan tahun lalu, senantiasa terpelihara dan diwarisi dari generasi ke generasi, yang sampai dewasa ini dirasakan dan dijalankan di Republik Rakyat Cina, Taiwan, serta negara-negara tetangganya yang dalam sejarah mendapatkan pengaruh kebudayaan Cina.

Secara garis besar, sejarah Cina pra republik sering dibagi menjadi dua periodisasi besar, yaitu jaman legenda dan feodalisme, yang diikuti dengan jaman kekaisaran. Masing-masing jaman tersebut dibagi-bagi lagi secara kronologis berdasarkan periode berkuasanya para penguasa serta dinasti-dinasti yang memerintah Cina.

Dengan demikian, maka kronologi sejarah Cina telah disusun sebagai berikut.

Jaman Legenda dan Feodalisme (fengjian 封建):

- 3 Penguasa and 5 Kaisar (Sanhuang Wudi 三皇五帝), 2500-2100 SM

- Dinasti Xia (Xia Chao) 夏朝), 2100-1600 SM

- Dinasti Shang (Shang Chao 商朝), 1600-1046 SM, populasi 13.7 juta jiwa

- Dinasti Zhou (Zhou Chao 周朝), 1046-256 SM: populasi 38 juta jiwa

- Zhou Barat (Xi Zhou 西周), 1046-771 SM

- Zhou Timur (Dong Zhou 東周), 770-221 SM

- Jaman Musim Semi dan Musim Gugur (Chunqiu Shidai 春秋時代), 771403 SM

- Jaman Negeri Berperang(Zhanguo Shidai 戰國時代), 475-221 SM

Jaman Kekaisaran:

- Dinasti Qin (Qin Chao 秦朝), 221-206 SM, populasi 20 juta jiwa

- Dinasti Han (Han Chao 漢朝), 206 SM - 220 M, populasi 57,6 juta jiwa

- Han Barat(Xi Han 西漢)

- Dinasti Xin (Xin Chao 新朝), 9-23, Kaisar Wang Mang 王莽

- Han Timur (Dong Han 東漢)

- Jaman Tiga Negeri (Sanguo Shidai 三國時代), 220-280

- Negeri Wei魏

- Negeri Shu蜀

- Negeri Wu吳

- Dinasti Jin 金朝 265-420, populasi 22,6 juta jiwa

- Jin Barat(Xi Jin) 西金

- Jin Timur dan 16 Negeri (Dong Jin Shiliu Guo 東金 十六國) 
- Dinasti Selatan dan Utara(Nanbei Chao 南北朝), 420-589

- Dinasti Sui (Sui Chao 隋朝), 589-618, populasi 46 juta jiwa

- Dinasti Tang (Tang Chao 唐朝), 618-907, populasi 80 juta jiwa (abad ke-9)

- Zhou Akhir (Hou Zhou 後周), 690-705

- Lima Dinasti dan 10 Negeri(Wudai Shiguo 五代十國), 907-960

- Dinasti Liao (Liao Chao 辽朝 907-1125

- Dinasti Song (Song Chao 宋朝), 960-1279, populasi 118,8 juta jiwa

- Song Utara (Bei Song 北宋)

- Song Selatan (Nan Song 南宋)

- Dinasti Jin/Khitan (Jin 金)

- Negeri Xixia 西夏

- Dinasti Yuan Mongol (Yuan Chao 元朝), 1271-1368, populasi 87,5 juta (tahun 1351)

- Dinasti Ming (Ming Chao 明朝 1368-1644), populasi 65 juta jiwa (tahun 1393), 160 juta (tahun 1600)

- Dinasti Qing Manzu (Qing Chao 清朝), 1644-1911, populasi 140 juta (tahun 1760), 301 juta (tahun 1790) Meningkat tajam antara 1749-1811 dari 117,495,000 jiwa menjadi 358,610,000 jiwa.

Bagi orang Cina, sejarah Cina dapat dikatakan dimulai dari periode yang dinamakan Sanhuang Wudi 三皇五帝 atau Tiga Penguasa dan 5 Kaisar, yaitu tokohtokoh mitologi prasejarah Cina. Kebenaran dari sejarah mereka belum dapat dipastikan secara faktual. Ada pun masa pemerintahan Dinasti Xia dikenal sebagai masa yang penting dalam sejarah peradaban Cina, karena merupakan dinasti pertama di Cina yang berlangsung selama 500 tahun yang dipimpin oleh 17 kaisar. Diperkirakan, daerah kekuasaan para penguasa Xia saat itu adalah daerah barat dari Propinsi Henan dan bagian selatan dari Propinsi Shanxi dewasa ini. Pada masa ini rakyatnya hidup sebagai petani dan menggunakan peralatan sederhana yang terbuat dari batu dan tulang. Beberapa peninggalan dari dinasti ini adalah perhiasan batu giok dan peralatan perunggu. Pertukaran komoditas juga sudah terjadi, dan mereka sudah mengenal penggunaan sistem penanggalan berdasarkan peredaran bulan dan matahari.

Dinasti ini kemudian digantikan oleh Dinasti Shang yang memerintah selama 600 tahun dengan 30 kaisar. Mereka menduduki wilayah Cina bagian utara dan tengah, dengan ibukotanya Anyang yang terletak di daerah Propinsi Henan. Penduduknya hidup sebagai petani dan juga peternak. Peninggalan jaman ini berupa perahu, peralatan perang, dan alat-alat rumah tangga dari perunggu. Aristokrasi sudah mulai dikenal pada jaman Shang, dimana seorang raja memimpin atas para penguasa militer. Para pemimpin wilayah diangkat oleh raja yang kemudian mendapatkan bantuan dari mereka apabila sang raja akan melakukan serangan militer terhadap lawannya. Di 
bawah kaum militer ini terdapat kaum pendeta, yang tugasnya mencatat administrasi pemerintahan sekaligus bertanggungjawab untuk masalah religi. Religi saat itu berdasarkan pada pemujaan leluhur serta para dewa. Dewa yang utama adalah Shangdi 上帝, yaitu Penguasa di Atas (Langit).

Periode Zhou dalam sejarah Cina dikenal sebagai periode pembentukan kebudayaan Cina, dan bisa dikatakan jaman dimana sejarah Cina mulai tercatat dengan baik. Periode ini juga dikenal sebagai periode "feodal" karena masa awal pemerintahan Zhou memiliki persamaan dengan pemerintahan abad pertengahan di Eropa, yaitu sistem pemerintahan yang bersifat sentralisasi. Namun sesungguhnya di luar persamaan ini ada juga sejumlah perbedaan penting lainnya. Salah satu perbedaan yang jelas ialah bahwa para pemimpin Zhou memimpin dari kota-kota bertembok dan bukan dari istana.

Istilah Cina untuk sistem Zhou ini adalah fēngjiàn (封建). Ketika sebuah dinasti terbentuk, wilayah yang dikuasai oleh seorang raja (wang王) dibagi menjadi tanahtanah perdikan atau feng 封 (fiefdom) yang dapat diwarisi, di mana mereka yang diberi tanah tersebut yaitu para adipati atau gong 公 secara berangsur akhirnya menjadi kuat dengan sendirinya. Tanah-tanah perdikan atau negara itu sendiri cenderung untuk membagi diri secara sistem feodal. Pada saat-saat tertentu, seorang adipati yang amat ambisus akan mengambil kekuasaan dari rajanya dan mempersatukan negaranya. Sentralisasi menjadi lebih penting ketika negara-negara mulai mengadakan perang di antara mereka dan sentralisasi itu sendiri cenderung mengobarkan lebih banyak peperangan. Ketika seorang adipati merebut kekuasaan dari para raja nya, maka negara yang terbentuk kemudian membutuhkan administrasi birokrasi yang dijalankan oleh para pejabat yang ditunjuk olehnya.

Pada jaman Zhou, kelas terendah yang memerintah disebut Shi (士). Ketika sebuah Kadipaten (wilayah yang diperintah oleh seorang adipati) disentralisasi, mereka ini akan mendapatkan pekerjaan sebagai pegawai atau pejabat pemerintah. Berbeda dengan seorang ksatria di Eropa, maka Shi diharapkan sebagai seorang sarjana atau cendekiawan. Ketika diangkat menjadi pegawai, mereka dapat berpindah-pindah dari sebuah negeri ke negeri lainnya. Ada dari mereka yang akan berkelana dari satu negeri ke negeri lainnya untuk menjajakan kiat-kiat reformasi administrasi atau militer. Dan mereka yang tidak mendapatkan pekerjaan sebagai pegawai, seringkali mengajar anakanak muda yang ingin mendapakan status dalam pemerintahan. Tokoh yang paling terkenal adalah Konfusius, yang mengajarkan sebuah sistem kewajiban mutualistis antara atasan dan bawahan. Berbeda dengan Konfusius adalah kaum Legalis yang ajarannya menganjurkan sebuah sistem aturan dan hukuman yang keras. Peperangan pada Masa Negara Berperang akhirnya diakhiri dengan kemenangan dinasti Qin yang sangat legalis. Ketika dinasti Qin runtuh dan digantikan oleh dinasti Han, banyak orang Cina merasa lega dan kembali kepada nilai-nilai Konfusius yang lebih manusiawi. 


\section{EMPAT JENIS PROFESI TRADISIONAL:}

Berbicara tentang shi, maka kita akan berbicara tentang empat jenis profesi yang dikenal dalam masyarakat Cina tradisional. Apa saja profesi yang dimaksud? Adaempat kategori manusia atau jenis profesi dalam masyarakat Cina tradisional atau yang dikenal dengan shi-nong-gong-shang士農工商, yang merupakan sebuah struktur hirarki kelas sosial yang dikembangkan pada jaman Cina kuno oleh para sarjana Konfusian atau Legalis sekitar masa akhir Dinasti Zhou周朝 (1046-256 SM), yaitu dinasti terpanjang dalam sejarah Cina. Empat jenis profesi ini dianggap sebagai sebuah bagian penting dari struktur sosial feodalisme atau fengjian 封建.

Secara berturut, hirarki ini dimulai dengan shi 士 (gentry sarjana), diikuti oleh nong 農 (petani/penggarap tanah), lalu kemudian gong 工 (artisan atau pengrajin), dan diakhiri dengan shang 商 (saudagar atau tengkulak). Kategori umum dan luas ini lebih merupakan sebuah idealisasi yang berbeda dengan kenyataan praktis, terutama ketika pada jaman Ming dan Qing. Hal ini terjadi disebabkan oleh komersialisasi masyarakat Cina pada jaman Song dan Ming, yang mengaburkan garis perbedaan antara empat hirarki sosial ini. Sistem ini juga tidak tergambar dalam semua kelompok sosial lainnya pada masyarakat pramodern Cina. Definisi dari identitas klas shi juga berubah dari masa ke masa, dari kasta prajurit di jaman kuno, berubah menjadi elit sarjana aristokrat, dan akhirnya menjadi sebuah elit sarjana birokrat yang tidak menekankan pada garis keturunan. Juga pernah terjadi sebuah fusi yang bertahap di antara klas pedagang kaya dengan klas gentry pemilik tanah, yang berakhir di akhir jaman Dinasti Ming. Sistem tatanan sosial ini juga diadopsi oleh bangsa-bangsa yang terkena pengaruh budaya Konfusianis, seperti Jepang, Korea dan Vietnam.

\section{SEJARAHTERBENTUKNYA EMPAT PROFESI}

Dari data-data karya susastra yang dapat diperoleh, tingkat sosial orang biasa mulai disusun pertama kalinya pada jaman Zhanguo Shidai (戰國時带403-221 SM). Namun, Ban Gu 班固 (32-92 M), seorang sejarahwan dan sastrawan dari jaman Han Timur (25-220 M) menulis dalam karyanya yang berjudul Han Shu 漢書 atau Kitab Sejarah Negeri Han bahwa empat jenis pekerjaan bagi orang biasa ini sudah ada pada jaman Zhou Barat (1050771 SM), yang dia anggap sebagai jaman keemasan. Namun dewasa ini diketahui bahwa empat jenis pekerjaan ini baru ada sejak abad ke dua sebelum Masehi. Oleh Ban Gu, hirarki sosial ini di jelaskan sebagai berikut: sarjana, petani, artisan/pengrajin dan saudagar/ tengkulak. Mereka yang berlajar untuk mendapatkan kedudukan dalam pemerintahan disebut shi 士 (sarjana atau orang terpelajar); mereka yang menggarap tanah dan menghasilkan padi/gandum dinamakan nong 農 (petani); mereka yang menggunakan ketrampilannya untuk membuat peralatan disebut gong工 (artisan/pengrajin); dan mereka yang mengangkut barang-barang berharga dan menjual komoditi dinamakan shang 商 (saudagar/tengkulak). Seorang ahli sejarah Cina menulis bahwa klasifikasi dari "empat 
jenis pekerjaan" dapat dilihat hanya sebagai sebuah alat retorika saja yang tidak memiliki pengaruh apa pun pada kebijakan pemerintah. Menurutnya, bahwa walaupun tidak ada pasal khusus tentang hal ini yang tercatat dalam kitab undang-undang dinasti Qin atau dinasti Han, namun ada undang-undang yang memperlakukan kelompok-kelompok sosial ini sebagai unit-unit yang terpisah dengan hak-hak khusus yang berbeda. ${ }^{2}$

\section{SARJANA/CENDEKIAWAN (SHI 士)}

Pada jaman dinasti Shang 商朝 (diperkirakan 1600-1046 SM, populasi 13.7 juta jiwa) dan dinasti Zhou 周朝 (1046-256 SM, populasi 38 juta jiwa) para cendekiawan ini dianggap sebagai sebuah strata sosial dari keturunan aristokrat tingkat-bawah. Klas sosial ini ditandai dengan hak mereka untuk mengendarai kereta kuda dan memimpin pertempuran dari kereta perang, sementara itu mereka juga melayani fungsi-fungsi sipil mereka. ${ }^{3}$

Mereka juga memiliki ciri khas dengan persenjataan yang mereka gunakan, yaitu pedang dengan tajam pada dua sisinya yang dinamakan jian 劍. Jenis pakaian yang dikenakan mereka juga membedakan mereka dengan yang lain, mereka mengenakan hanfu 漢服, sementara yang lain memakai pakaian biasa yang berbeda.

Pada jaman Zhanguo Shidai peperangan menggunakan kereta kuda digantikan oleh unit kaveleri dan infantri yang mengandalkan para pemanah, maka partisipasi para shi ini menjadi tersingkirkan. Saat itu para raja dan adipati mencari orang-orang yang dilatih secara militer, bukan saja karena latar belakang aristokratnya. ${ }^{4}$ Ini juga bersamaan dengan periode dimana ajaran-ajaran filosofi berkembang di Cina, dimana cita-cita sebagai cendekiawan menjadi sesuatu yang amat dihargai di antara para negarawan. ${ }^{5}$ Dengan demikian, para shi ini pada akhirnya menjadi terkenal bukan karena ketrampilan mereka sebagai pendekar, tetapi karena kecendekiawannya, kemampuan mereka di bidang administrasi, dan kemampuan mereka dalam mengumandangkan etika dan moralitas yang didukung oleh ajaran-ajaran filsafat yang saling berkompetisi itu. ${ }^{6}$

Di bawah pemerintahan Qin Xiaogong秦孝公 (381 - 338 SM), atau Adipati Xiao dari Qin, dan Shang Yang商鞅 (390 BC - 338 BC), seorang menteri utama dan reformer saat itu, negeri Qin ditransformasi oleh sebuah filosofi yang bersifat meritokrasi namun

2 Barbieri-Low, Anthony J. (2007). Artisans in Early Imperial China. Seattle \& London: University of Washington Press, hal 37

3 Ebrey, Patricia Buckley Anne Walthall, James Palais. (2006). East Asia: A Cultural, Social, and Political History. Boston: Houghton Mifflin Company, hal 22

4 Ebrey, Patricia Buckley Anne Walthall, James Palais. (2006). East Asia: A Cultural, Social, and Political History. Boston: Houghton Mifflin Company, hal 29-30

5 Ibid., hal 32

6 Ebrey, loc.cit. hal 32-39 
keras, yaitu Fajia 法家 atau Legalisme. Filosofi ini menekankan pada pemberian hukuman yang keras bagi mereka yang mengabaikan aturan-aturan yang sudah diketahui secara publik, sementara itu memberikan penghargaan bagi mereka yang bekerja untuk negeri dan berusaha keras untuk mengikuti aturan-aturan. Ini adalah sebuah cara untuk mengurangi kekuasaan dari kaum bangsawan, dan merupakan sebuah kekuatan lain yang berada di belakang transformasi dari klas shi ini, dari aristokrat-prajurit menjadi pejabat yang mengejar meritokrasi. Dinasti Qin mempersatukan Cina di bawah sistem Legalis, tetapi kemudian menjadi sangat dibenci karena cara-cara mereka yang opresif, sehingga kemudian Cina terjerumus ke dalam sebuah situasi perang saudara.

Pemenang dari perang saudara ini adalah Liu Bang劉邦 (247-195 SM), bergelar Han Gaozu 漢高祖, yang mendirikan Dinasti Han yang berlangsung selama empat abad. Salah satu dari penggantinya adalah Han Wudi漢武帝atau Kaisar Wu (memerintah 14187 SM), yang bukan saja merekatkan ideologi Konfusius ke dalam arus utama pemikiran, kepemerintahan, dan tatanan sosial Cina saat itu, tetapi juga memasukan sebuah sistem rekomendasi dan nominasi dalam pelayanan pemerintah yang dikenal dengan xiaolian 孝廉 atau kepatuhan dan non-koruptif. Kaisar Wu memerintahkan setiap distrik untuk merekomendasikan seorang kandidat yang patuh dan satu kandidat yang non-koruptif untuk dijadikan pejabat sipil. Di kemudian hari nominasi ini dijadikan rekrutmen proporsional oleh Kaisar He, yang memilih satu kandidat bagi 200,000 penduduk, dan satu kandidat bagi setiap 100,000 penduduk di daerah-daerah minoritas etnis. Sang nominator juga bertanggung jawab jika calonnya kemudian didakwa korupsi, dan dapat dihukum jika dia menolak untuk menominasi orang-orang yang memenuhi syarat.

Setelah jaman Han, sistem ini digantikan oleh Jiu pin zhong zheng zhi九品中正制 atau dikenal dengan istilah nine-rank system, sebuah cara yang sama untuk menseleksi calon pejabat melalui rekomendasi. Ini merupakan sebuah sistem nominasi untuk pegawai negeri pada jaman Sanguo dan Nanbeichao. Sistem ini juga sistem yang digantikannya sesungguhnya lebih memilih mereka yang kaya, yang mempunyai latar belakang bangsawan, dan mereka yang mempunyai koneksi. Secara teoretis, otoritas pemerintah lokal diberikan tugas untuk memilih kandidat yang bertalenta, kemudian memilah mereka ke dalam sembilan tingkatan sesuai dengan kemampuan mereka. Tetapi, dalam prakteknya, hanya mereka yang berasal dari keluarga kaya dan berkuasa saja yang akan dipilih. Barulah pada jaman Dinasti Sui terjadi sebuah perubahan dalam klas shi dengan berdirinya sistem keju科舉 atau sistem ujian bagi pegawai negara.

Sistem ujian bagi pegawai negara yang berlangsung pada dinasti Tang adalah mengikuti model Sui yaitu rekrutmen parsial bagi mereka yang telah lulus ujian standar dan memperoleh gelar resmi (yaitu ujian yang meliputi enam bidang seni: musik, memanah dan berkuda, aritmatika, menulis, dan pengetahuan tentang ritual dan tatacara). Namun rekrutmen melalui rekomendasi untuk mendapatkan jabatan masih sangat kuat pada dua dinasti ini. Baru lah pada jaman Dinasti Song rekrutmen bagi 
mereka yang lulus dari ujian dan menerima gelar resmi diberi penghargaan yang lebih. ${ }^{7}$

Saat itu ada dua jenis ujian yang diberikan, yaitu mingjing 明經dan jinshi 進士. Mingjing adalah ujian berdasarkan klasika Konfusian, dan menguji pengetahuan siswa yang diambil dari berbagai teks. Jinshi adalah ujian yang menguji kemampuan susastra sang siswa dalam menulis jawaban-jawaban secara esei atas pertanyaan-pertanyaan mengenai masalah kepemerintahan dan politik, juga ketrampilan mereka dalam menyusun puisi. Para kandidat juga dinilai untuk sikap, penampilan, kemampuan berbicara, dan ketrampilan dalam kaligrafi. Semua ini adalah kriteria subjektif yang mempermudah bagi mereka yang sudah menjadi bagian dari masyarakat yang kaya untuk dipilih daripada mereka yang kurang berada yang tidak mampu untuk mendapatkan pendidikan yang canggih. Ada ketimpangan dalam jumlah pejabat sipil yang berasal dari aristokrasi dengan mereka yang bukan. Ujian ini terbuka bagi semua laki-laki yang ayahnya bukan dari klas gong atau shang, meskipun mereka yang kaya atau memiliki status bangsawan bukanlah prasyarat untuk mendapatkan rekomendasi. Agar dapat mempromosikan pendidikan Konfusian secara meluas, pemerintah Tang mendirikan sekolah-sekolah negeri dan mengeluarkan versi standar dari kitab Wujing 五經yang diberikan komentar-komentar terpilih.

Prosedur kompetitif ini dirancang untuk semaksimal mungkin menjaring talenta terbaik bagi pemerintah. Tetapi mungkin karena yang menjadi pertimbangan para penguasa Tang, yang menyadari bahwa ketergantungan kekaisaran pada keluargakeluarga aristokrat dan warlords yang kuat akan membawa konsekuensi terjadinya destabilisasi, maka mereka menciptakan pejabat-pejabat karir yang tidak memiliki teritorial yang otonom atau basis kekuasaan yang fungsional. Tang menyusun undangundang yang memastikan pembagian yang sama untuk properti yang diwarisi di antara ahli waris yang sah, memperbolehkan mobilitas sosial dan mencegah keluarga-keluarga dari pejabat istana yang berkuasa untuk menjadi bangsawan pemilik tanah melalui pewarisan melalui anak laki-laki. Dari jaman Tang sampai akhir dinasti Qing, para pejabat-sarjana sering berfungsi sebagai perantara antara tingkat akar rumput dengan pemerintah. Namun potensi dari penyebaran sistem ujian ini barulah terlaksana pada jaman Song, dimana para pejabat-sarjana saat itu lebih mengejar merit dan menanggalkan kebiasaan aristoraktik mereka serta mendefinisikan status sosialnya melalui ujian. Adalah dinasti Sui dan dinasti Tang yang melembagakan dan menciptakan pijakan bagi sistem pegawai negeri dan klas elit baru pejabat- sarjana yang direkrut dari sistem ujian.

Kelas Shi juga menjadi kurang aristokratik dan lebih birokratis karena sifat ujian yang sangat kompetitif pada jaman Song. ${ }^{8}$ Dari abad ke-11 sampai abad ke-13, jumlah

\footnotetext{
7 Ebrey, Patricia Buckley Anne Walthall, James Palais (1999). The Cambridge Illustrated History of China. Cambridge: Cambridge University Press, hal 145-146

8 Ebrey, Patricia Buckley Anne Walthall, James Palais. (2006). East Asia: A Cultural, Social, and Political
} 
kandidat yang mengikuti ujian meningkat secara tajam dari 30,000 menjadi 400,000 di akhir dinasti ini. Dengan adanya teknologi percetakan yang ada saat itu sangat membantu penyebaran pengetahuan di antara masyarakat melek huruf, membuat lebih banyak orang berminat untuk menjadi kandidat dan kompetitor dalam memperebutkan gelar yang terhormat. ${ }^{9}$ Dengan melonjaknya jumlah penduduk secara dramatis maka meningkat pula jumlah kaum gentry, para pejabat-sarjana membutuhkan kaum gentry untuk melakukan jasa lokal seperti mendanai pekerjaan umum, sekolah-sekolah di tingkat prefektur, atau membantu dalam menarik pajak. ${ }^{10}$

Sesungguhnya ada cukup banyak kelompok sosial lainnya yang dikeluarkan dari empat kategori luas dalam hirarki sosial ini. Termasuk di dalamya yaitu tentara dan penjaga, para pendeta dan ahli nujum, kasim dan selir, para penghibur dan dayangdayang, pembantu rumah tangga, budak, pelacur, dan buruh. Kaisar sebagai perujudan dari mandat ilahi yang memiliki otoritas kehakiman dan eksekutif - berada di atas tingkatan sosial dan legal dari kaum gentry dan pejabat-sarjana ini. Meskipun keluarga kerajaan dan keluarga besarnya juga sangat dihormati, mereka tidak memiliki otoritas komando dalam tingkat yang sama.

Ada motivasi-motivasi yang berada di belakang pengklasifikasian dari pejabat aristorasi dan kemudian pejabat-sarjana ini oleh kelompok tertentu dalam hirarki, dengan menghilangkan yang lainnya. Pejabat-sarjana menempatkan para petani sebagai kelompok kedua yang paling terhormat karena pejabat aristoraktik dan pejabat-sarjana adalah juga para pemilik tanah, yang hampir sama dengan para petani (mereka yang bukan petani penggarap atau buruh tani). Para petani dan artisan ditempatkan pada kedudukan yang lebih tinggi dari kaum saudagar karena mereka menghasilkan produk pertanian dan memproduksi barang jadi, benda-benda penting yang dibutuhkan oleh seluruh masyarakat. Kaum saudagar dipandang hanya memiliki talenta dalam berdagang dan jual beli, dan sering dianggap rakus dan bahkan parasit terhadap kebutuhan dari kelompok lainnya.

Prajurit juga dikeluarkan dari hirarki sosial karena para sarjana-gentry merangkul pendidikan intelektual (atau wen 文) dan membenci kekerasan (atau wu 武). ${ }^{11}$ Para

History. Boston: Houghton Mifflin Company, hal 159

9 Fairbank, John King and Merle Goldman (1992). China: A New History; Second Enlarged Edition (2006). Cambridge: MA; London: The Belknap Press of Harvard University Press, hal 94

${ }^{10}$ Fairbank, John King and Merle Goldman (1992). China: A New History; Second Enlarged Edition (2006). Cambridge: MA; London: The Belknap Press of Harvard University Press, hal 101-106. Michael, Franz. "State and Society in Nineteenth-Century China," World Politics: A Quarterly Journal of International Relations (Volume 3, Number 3, April 1955): hal 420-421. Yuan, Zheng. "Local Government Schools in Sung China: A Reassessment," History of Education Quarterly (Volume 34, Number 2; Summer 1994): hal 196-199

${ }^{11}$ Fairbank, John King and Merle Goldman (1992). China: A New History; Second Enlarged Edition (2006). Cambridge: MA; London: The Belknap Press of Harvard University Press, hal 109 
sarjana tidak ingin melegitimasi mereka yang profesinya bertumpu semata-mata pada kekerasan, jadi dengan mengeluarkan mereka dari hirarki sosial merupakan cara untuk membuat mereka tidak dikenal dan tidak menonjol dalam strata sosial.

Para penghibur dan pelayan istana seringkali tergantung pada orang kaya dan dikaitkan dengan kesenangan imoral dari distrik-distrik hiburan di perkotaan. Untuk memberikan pengakuan resmi akan memberikan mereka kehormatan yang lebih. Meski pun para shaman dan ahli nujum pada Jaman Perunggu Cina mempunyai otoritas tertentu sebagai pemimpin religius dalam masyarakat, para sarjana tidak menginginkan para pemimpin relijius memiliki kekuasaan dan pengaruh yang terlalu besar sebagaimana penguasa-penguasa militer (contohnya adalah Zhang Jue/Jiao 張角 (wafat $184 \mathrm{M}$, yang memimpin sebuah sekte Taois melakukan pemberontakan terbuka menentang otoritas pemerintahan Han). Ada juga berbagai pemberangusan terhadap Budisme di Cina, kebanyakan dari ketidakpuasan ini dikarenakan pertapaan Buddis menghindari pajak, tetapi juga karena para sarjana Neo Konfusian menganggap Budisme adalah sebuah ideologi asing dan mengancam tatanan moral dari masyarakat.

Para kasim (eunuch) istana adalah golongan yang dihormati sekaligus dicurigai oleh para pejabat-sarjana, karena ada beberapa kejadian dalam sejarah Cina dimana para kasim yang mempunyai kekuasaan kemudian mendominasi kaisar, istana, dan seluruh pemerintah pusat. Pekerjaan dan tanggung jawab mereka yang cukup penting di dalam istana membuat mereka memiliki otoritas yang disegani. Sehingga, ada beberapa kasus di mana mereka akhirnya sering terjebak ke dalam pergulatan kekuasaan di dalam istana. Contoh yang ekstrim adalah kasim Wei Zhongxian 魏忠賢 (1568-1627) yang dikritisi oleh kaum ortodoks dari Akademi Donglin 東林書院karena mempengaruhi Kaisar Tianqi yang buta huruf dan tidak berminat menjalankan tugasnya. Wei akhirnya dipecat oleh kaisar berikutnya, sehingga dia akhirnya bunuh diri. ${ }^{12}$

\section{KAUM GENTRY CINA PADA JAMAN DINASTI MING DAN QING}

Pada jaman Ming dan Qing, ada tiga birokrasi yang berada pada posisi tertinggi, yaitu militer atau tentara, departemen hukum dan departemen administratif. Di bawahnya ada enam kementerian dan seluruh kantor propinsi dan distrik. Pada masa ini tercatat bahwa Kaisar lebih banyak mengeluarkan biaya daripada dinasti-dinasti sebelumnya; pada tahun 1580an, pemerintah menghabiskan seluruh uang tunai untuk menjalankan pemerintahan, karena mereka menghabiskan uang untuk tentara, sehingga akhirnya negara bangkrut. Hal ini terjadi selama limapuluh tahun terakhir pemerintahan dinasti Ming.

Pada paruh kedua abad ke-17, orang-orang Manzu yang menggantikan dinasti Ming kemudian berhasil mengembalikan sebuah pemerintahan kekaisaran yang

\footnotetext{
12 Spence, Jonathan D. (1999). The Search for Modern China; Second Edition. New York: W. W. Norton \& Company, hal 17-18
} 
kuat sebagaimana kekaisaran Ming pada masa jayanya. Salah satu sebab utamanya ialah bahwa para pejabat dan pegawai negerinya sangat efisien dan trampil dalam melaksanakan tugasnya. Mereka juga sangat percaya pada sistem pemerintahan yang dianggap sudah baik. Oleh karenanya, para pejabat dan pegawai pemerintah ini diberi banyak otoritas dan dan kemudahan oleh istana. Di awal abad ke enambelas ketika orang Portugis tiba di Cina, mereka menyebut para pejabat ini dengan nama 'mandarin.'

Pada saat itu banyak orang yang ingin mendapatkan pekerjaan sebagai pegawai pemerintah karena memang mobilitas sosial sangat dimungkinkan, namun dalam kenyataannya sangat sulit untuk berhasil lolos dalam ujian masuk menjadi seorang pegawai. Apalagi ketika saat itu penduduk bertambah dan sekolah semakin banyak jumlahnya, persaingan untuk mendapatkan pekerjaan di pemerintahan semakin ketat.

Pertama, sang kandidat harus diwawancara di kantor distrik. Setelah lolos wawancara, dia diperbolehkan untuk mengikuti ujian pada tingkat distrik. Jika sang kandidat tersebut berhasil lulus ujian tingkat distrik, maka dia akan menjadi seorang anggota dari kelas gentry dan dia dibebaskan dari kerja badan yang diwajibkan oleh negara kepada warga biasa. Biasanya, butuh beberapa tahun serta uang yang cukup besar untuk mempersiapkan ujian ini. Pada masa itu, ada sekitar setengah juta orang lulus ujian tingkat distrik setiap tahun. Tahap kedua adalah mengikuti ujian tingkat propinsi yang dilakukan di ibukota propinsi, yang jadwalnya dilakukan hanya sekali dalam tiga tahun. Catatan saat itu menunjukkan bahwa rata-rata hanya satu dari seratus orang yang lulus. Ada pun ujian tertinggi yang harus ditempuh adalah ujian tingkat metropolitan yang dilaksanakan di Beijing, yang juga hanya dilakukan setiap tiga tahun. Saat itu, mereka yang lulus dari ujian ini tercatat rata-rata kurang dari 90 orang dari seluruh jumlah peserta yang berasal dari seluruh negeri.

\section{KEJU 科举 - SISTEM UJIAN NEGARA UNTUK MENERIMA PEGAWAI KEKAISARAN}

Sistem ujian negara terdiri dari sejumlah ujian yang berat yang dilaksanakan di tingkat distrik, propinsi dan metropolitan. Quota yang ketat membatasi jumlah kandidat yang berhasil dalam setiap ujian, misalnya, hanya tiga ratus siswa yang dapat lulus pada ujian tingkat metropolitan. Sudah menjadi hal yang umum terjadi bahwa seorang siswa seringkali mengikuti beberapa kali ujian sebelum mereka berhasil mendapatkan gelar; banyak pula yang gagal lulus di berbagai tingkatan.

Proses untuk mengikuti sistem ujian keju ini dapat digambarkan sebagai berikut ini. Setiap siswa yang akan mengikuti ujian tiba di kompleks tempat ujian dengan hanya membawa beberapa barang yang dibutuhkan: sebuah botol air, pispot, peralatan tidur, makanan, batu tempat tinta, tinta, dan kuas. Para penjaga akan memastikan identitas para siswa dan memeriksa mereka untuk mencari barang-barang cetak yang disembunyikan. Setiap siswa yang akan mengikuti ujian menghabiskan tiga hari dan 
dua malam untuk menulis八股文 bāguwén ${ }^{13}$ atau “eight-legged essays" - komposisi susastra dengan delapan bagian yang berbeda - dalam sebuah ruangan kecil yang berisi tempat tidur, meja, dan kursi. Selama tiga hari tidak boleh terputus, dan mereka tidak diperbolehkan berkomunikasi dengan cara apa pun. Jika seseorang meninggal pada saat ujian, maka jasad mereka akan dibungkus dengan tikar oleh petugas dan dilempar keluar pagar tinggi yang mengelilingi kompleks ujian. Ujian ini senantiasa sangat kompetitif, namun gelar apa pun di tingkat apa pun yang diperoleh oleh seorang sarjana tidak dapat memastikan dia untuk bisa diterima sebagai pegawai pemerintah. Tentunya, mereka yang hanya lulus pada ujian tingkat distrik mempunyai kesempatan yang lebih buruk untuk menjadi bagian dari birokrasi kekaisaran daripada mereka yang lulus pada ujian tingkat metropolitan. Pada masa Dinasti Qing, satu juta sarjana bergelar harus berkompetisi untuk mendapatkan 20,000 posisi dalam birokrasi. Mereka yang tidak mendapatkan tempat pada birokrasi pemerintahan menghabiskan karir mereka "menggunakan kemampuan menulis" dengan menjadi guru lokal di tempat asal mereka.

Ada sejumlah jenis gelar yang ditawarkan bagi mereka yang lulus dalam sistem ujian keju ini:

1) Shengyuan 生員 juga disebut xiucai 秀才, atau orang yang mendapat lisensi. Gelar ini dianugerahkan kepada mereka yang lulus ujian yang diadakan setiap tahun pada tingkat xian 縣 atau sub-prefecture (setingkat distrik). Seorang shengyuan yang lulus ranking pertama dinamakan anshou 案首.

2) Juren 举人 atau orang yang terekomendasi. Ini adalah gelar kesarjanaan yang dianugerahkan kepada para lulusan tingkat propinsi, yaitu mereka yang lulus ujian yang diselenggarakan pada tingkat propinsi yang diadakan setiap tiga tahun. Jieyuan 解元 adalah gelar yang diberikan kepada juren yang lulus nomor satu, sedangkan Huiyuan 會元 adalah gelar yang diberikan kepada juren yang lulus nomor satu dalam prakualifikasi.

3) Gongshi 貢士, atau sarjana yang mendapat penghargaan, adalah gelar bagi

\footnotetext{
${ }^{13}$ Delapan bagian itu masing-masing adalah: 1) Pembukaan/ poti (破題): Berisi prosa-prosa dua kalimat yang fungsinya adalah untuk menjelaskan topik yang akan ditulis; 2) Penegasan/ chengti (承題): Berisi prosa lima kalimat, yang mengelaborasi dan menjelaskan tema; 3) Komposisi awal/ qijiang (起 講): Penulisan prosa; 4) Argumen awal/ qiban (起股): Nomor yang tertentu (4, 5, 8 or 9) dari kalimatkalimat yang dipasangkan ditulis secara paralel, untuk membangun argumen awal. Kalimat-kalimat paralel menjelaskan topik dan menyampaikan pengertian yang sama, dengan struktur yang sama tetapi menggunakan kata-kata berbeda; 5) Argumen tengah/ zhongban (中股): Kalimat-kalimat ditulis secara paralel, dengan kalimat-kalimat yang ditulis secara paralel, dimana titik pusat dari esei ini dibeberkan dengan bebasnya; 6) Argumen akhir/houban (後股): Kalimat-kalimat ditulis secara paralel, tidak dibatasi jumlahnya. Pokok-pokok yang tidak diajukan pada bagian sebelumnya didiskusikan disini; jika tidak, penulis boleh terus menambahkan idenya dalam argumen sentral. Bagian ini ditulis dengan serius berdasarkan realisme; 7)Argumen penutup/ suban (束股): Kelompok-kelompok kalimat paralel, setiap kelompok terdiri dari dua sampai tiga, atau empat sampai lima baris. Tema utama disini dimunculkan kembali dan dipertautkan dengan hal-hal yang bersangkutan; dan 8) Konklusi/ dajie (大結): penulisan prosa dimana ekspresi bebas dan kreatifitas diperbolehkan. Konklusi diberikan disini.
} 
mereka yang berhasil lulus pada tingkat nasional atau metropolitan. Ujian ini diselenggarakan pada musim semi setelah ujian tingkat propinsi pada Ministry of Rites (Lì Bù 禮部) di ibukota negara.

4) Jinshi 進士, atau sarjana yang terkemuka, seorang lulusan dari ujian yang diadakan di istana kekaisaran, diselenggarakan di ibukota negara segera setelah ujian tingkat metropolitan setiap tiga tahun. Ujian kekaisaran tingkat final ini berada langsung dalam pengawasan kaisar dari dinasti yang sedang berkuasa. Hanya para Gongshi yang mendapatkan kesempatan untuk mengikuti ujian ini. Ada gelar-gelar khusus bagi mereka yang berjaya dalam ujian istana ini, yang terdiri dari tiga tingkat kesempurnaan:

a） 進士及第 jinshi jidi, mereka yang berada pada ranking pertama, yang disusun dalam tiga tingkatan:

1) 状元 zhuangyuan: harafiah, kebanggaan negara, bagi mereka yang lulus terbaik

2) 榜眼 bangyan: bagi mereka yang lulus terbaik berikutnya atau kedua

3) 探花 tanhua: bagi mereka yang lulus terbaik ketiga

b) 進士出身 jinshi chushen, bagi mereka yang berada pada ranking kedua, di bawah tanhua.

c）同進士出身 tong jinshi chushen, bagi mereka yang berada pada ranking ketiga dalam ujian istana.

Kedudukan mereka dalam masyarakat berada di bawah kaum birokrasi elit dan di atas orang biasa di pedesaan. Kepala distrik adalah tingkat terbawah dari birokrasi pemerintah. Pada jaman Ming dan Qing, penduduk Cina berlipat enam kali dari jumlah sebelumnya, tetapi jumlah kepala distrik hanya bertambah dari 1170 menjadi 1470. Seorang kepala distrik harus berasal dari luar wilayah tempat dia bekerja. Ini dikarenakan dia tidak boleh terlalu dekat dengan penduduk setempat. Dia memiliki banyak sekretaris dan penasehat. Tetapi jika dia ingin memerintah dengan baik, dia harus mendapatkan dukungan dari gentry lokal.

Ada pun yang disebut dengan gentry Cina ini sama sekali berbeda dengan para pemilik tanah kaya raya seperti di Inggris. Gentry Cina kebanyakan hidup di kota-kota pasar atau kota-kota terbesar yang ada di setiap distrik. Mereka biasanya memiliki tanah sebagai tuan tanah, yang berarti mereka tidak harus mengolah tanahnya sendiri. Mereka mampu untuk menyekolahkan anak-anak mereka ke sekolah-sekolah privat yang membutuhkan biaya besar. Ketika menjabat, seringkali mereka berada di luar dari wilayah dimana mereka memiliki tanah, dan banyak kisah dan cerita yang menggambarkan bahwa mereka tidak terlalu baik kepada orang-orang yang mengerjakan tanahnya. Gentry Cina juga adalah pemimpin-pemimpin lokal; mereka seringkali mewakili penduduk lokal dan berbicara kepada birokrasi atas nama rakyat setempat. Mereka juga turut mengelola dan seringkali bertindak sebagai pelindung 
bagi sekolah-sekolah dan kuil-kuil Konfusius setempat agar pendidikan dan sistem religi di tempat mereka tetap berjalan baik dan harmonis. Selain itu, kaum gentry Cina ini turut berpartisipasi dan bertanggung jawab atas ketersediaan fasilitas umum di lingkungannya; memperbaiki jalan, jembatan, kanal, dan saluran air. Kebanyakan para pejabat birokrasi Cina dari tingkat distrik sampai istana berasal dari kelas gentry ini. Ini adalah kelas aristokrasi yang memastikan bahwa rakyat mengikuti pemikiran dan keyakinan berdasarkan ajaran dan etika Konfusius.

\section{KAUM GENTRY CINA DI ABAD KE-19}

Oleh para peneliti Barat, banyak upaya telah dilakukan untuk mendefinisikan mereka secara tepat, yaitu, para pemilik tanah yang telah mengikuti sistem ujian kekaisaran yang dinamakan keju 科举, sehingga memenuhi persyaratan untuk memegang jabatan dalam pemerintahan, para pejabat yang sudah pensiun atau keluarga serta keturunan mereka.

Sistem ujian kekaisaran ini pada jaman dahulu disusun untuk memilih pegawai administrasi yang terbaik untuk birokrasi negara. Sistem ujian ini pertama kali dibentuk pada tahun 605 M, pada masa Dinasti Sui (561-618), kemudian dikembangkan dan menjadi matang pada jaman Dinasti Tang (618-907), berlangsung berabad-abad lamanya sampai akhirnya diakhiri sebagai sebuah institusi pada tahun 1905 oleh dinasti terakhir di Cina, yaitu Dinasti Qing (1644-1911). Institusi ini dianggap secara langsung bertanggung jawab dalam membentuk sebuah klas pejabat-sarjana/birokrat tanpa melihat garis keturunan.

Sistem ujian ini pernah ditutup pada saat orang-orang Mongol dari Dinasti Yuan mulai berkuasa, tetapi kemudian dihidupkan kembali pada tahun 1315 pada jaman Kaisar Renzong 元仁宗 (bertahta 1311-1320). Sistem ujian ini berkembang kembali di bawah dua dinasti terakhir, Dinasti Ming dan Dinasti Qing. Setelah Pemberontakan Boxer di tahun 1900-1901, pemerintah Qing mengorganisir sejumlah reformasi yang luas dan akhirnya menutup sistem ujian ini. Pada tanggal 2 September 1905 kaisar mendukung sebuah petisi yang memerintahkan bahwa sistem ujian kuno ini diberhentikan pada setiap tingkat di tahun berikutnya. Sistem ujian baru menyediakan kesetaraan bagi gelar-gelar lama; sarjana misalnya, dianggap setara dengan xiucai. Rincian dari sistem baru tersebut sedang digarap, namun belum selesai sampai akhir jatuhnya kekaisaran Cina yang terakhir ini pada tahun $1911 .^{14}$

Etienne Balazs, seorang sinolog asal Perancis pernah mengajukan pertanyaan, dalam upaya untuk menyusun sebuah definisi tentang kategori sosial unik masyarakat kekaisaran Cina ini: "How should the gentry, a dominant social group, which was peculiar

\footnotetext{
${ }^{14}$ Lihat Wolfgang Franke, The Reform and Abolition of the Traditional China Examination System (Cambridge, Massachusetts: East Asian Research Center, 1968), hal. 70-71.
} 
to China and unknown in other societies, be defined?" 15 Memang tidak mudah untuk menyusun sebuah definisi yang tepat bagi mereka. Sudah banyak definisi yang ada yang disusun oleh para sarjana Barat mengenai kaum gentry Cina ini, antara lain E.T.C. Werner, Max Weber, dan K.A. Wittfogel. Dalam upaya mereka untuk mendefinisikan kategori sosial ini setelah mengamati berbagai aspek dari peran mereka dalam masyarakat, secara umum dapat dikatakan, mereka mendefinisikan kaum gentry Cina sebagai sebuah kelompok sosial yang menghalangi kemajuan masyarakat, tidak berkontribusi bagi perkembangan kapitalisme, dan menjalankan kekuasaannya terhadap rakyat petani yang jumlahnya sangat banyak. ${ }^{16}$

Balazs sendiri tidak merasa nyaman dan merasa kesimpulan itu tidak pantas untuk terminologi gentry, dan menyatakan bahwa hal itu tidak jujur dengan konsepkonsep Cina. ${ }^{17}$ Dia lalu menyusun kategori gentry Cina ke dalam sebuah kategori yang memiliki dua esensi, yang berhubungan dengan sifat mendua mereka sebagai pegawai/ pejabat pemerintah dan juga sebagai literati; sebagai sebuah klas dan sebuah kasta dari sebuah aristokrasi intelektual yang tertutup, ${ }^{18}$ yang mendominasi penulisan Sejarah Resmi Cina, atau Zheng Shi. ${ }^{19}$ Balazs menyebut mereka scholar-officials. 15 Etienne Balazs, Chinese Civilization and Bureaucracy: Variations on a Theme. Transl. by H.M. Wright and
edited by Arthur F. Wright (New Haven \& London: Yale University Press, 1970), hal. 6 .

16 Chang Chung-li. The Chinese Gentry (Seattle: University of Washington Press, 1955), pp. xiv-xvi. Kesimpulan ini diambil dari bagian Introduction buku ini yang ditulis oleh Franz Michael.

17 Balazs, loc. cit. p 19.

18 Ibid., pp. 6-7. Balazs lalu menyusun sebuah terminologi mendua bagi gentry Cina: the scholar-officials.

19 Zheng Shi 正史, Kitab Sejarah Resmi Dinasti-Dinasti di Cina, terdiri dari 25 kitab sejarah tentang dinastidinasti di Cina yang dimulai dengan Shiji 史記, Records of the Grand Scribe, ditulis oleh Sima Tan 司馬談 (wafat sekitar 110 SM) dan putranya Sima Qian 司馬遷 (145 - 86 SM), keduanya adalah ahli perbintangan istana, atau taili 太史, pada masa Dinasti Han yang Pertama (Qian Han 前漢, 206 SM - 8 M). Pola dari karya historiografi Sima Qian sangat unik dan menjadi contoh bagi sejarah resmi dari dinasti-dinasti kekaisaran sejak saat itu sampai dua ribu tahun kemudian. Sejarah resmi dinasti-dinasti di Cina disusun dalam sebuah korpus yang dinamakan “Twenty-four histories” atau 二十四史. Setelah berakhirnya kekaisaran Cina pada tahun 1911, draft sejarah Qing yaitu Qingshigao 清史稿, ditambahkan ke dalam korpus ini. Qingshigao bukanlah sebuah sejarah "resmi" kedinastian karena tidak ada lagi kaisar atau dinasti penerus yang akan mengakuinya. Korpus ini lah yang kemudian dikenal dengan “Twenty-five histories” atau二十五史. Sebuah sejarah lainnya kemudian dimasukan ke dalam koleksi ini, yaitu Xin Yuanshi 新元史 atau “Sejarah Dinasti Yuan Baru", sehingga namanya menjadi “Twenty-six histories” atau 二十六史. Sima Qian menggunakan jenis catatan biografi, yang dikenal dengan nama historiografi jizhuanti 紀傳体 dan bukan jenis annal yang mencatat tahun demi tahun, atau biannianti 编年体. Ini disebabkan karena tingginya penghargaan bagi individu dan garis keturunan dalam sejarah Cina. Sejarah dari sebuah dinasti adalah sejarah sebuah keluarga atau puak, dan bukan sejarah dari sebuah negeri. Kitab Shiji ini terdiri dari lima jenis bab: 1 . Benji 本紀 atau annals : biografi kekaisaran dari para penguasa/kaisar, 2. Biao 表 : Tables; berisikan ringkasan dari masa pemerintahan dari para raja dari negeri-negeri feodal dari dinasti Zhou sampai awal dinasti Han. Pada saat yang sama hal-hal terpenting dari masa pemerintahan mereka juga disebutkan. 3. Shu書 later called zhi 志, rarely kao 考: Treatises; catatan tentang tatacara, penanggalan, musik, astronomi, sungai dan kanal, upacara persembahan religius, dsb. 4. Shijia 世家: biografi dari keluarga raja feodal dan orangorang yang terkenal, dan 5. Liezhuan 列傳: biografi dari orang-orang biasa dan biografi kolektif dari para maharani, pejabat, dan laporan-laporan dari negeri seberang. Empat kitab pertama sejarah resmi dinasti yaitu Shiji, Hanshu 漢書, Houhanshu 後漢書, dan Sanguozhi 三國志 dinamakan “Four Histories”. 
Fairbank juga menyatakan bahwa gentry Cina "is a technical term with two principal meanings and an inner ambiguity." ${ }^{20}$ Sifat mendua dari gentry ini kemudian didefinisikan lebih jauh lagi oleh Wakeman sebagai sebuah kelompok status dan sebuah klas. ${ }^{21}$ Gentry Cina telah memonopoli kehidupan politik, budaya, dan intelektual Cina sejak abad ke-11, yang menurut Chang Chung-li, yang karena dominasinya ini membuat proses transisi dari Ming ke Qing dapat dimungkinkan. ${ }^{22}$

Dalam karyanya yang terkenal, Rebellion and Its Enemies in Late Imperial China: Militarization and Social Structure, 1796-1864, Kuhn menulis,

"....it was this elite, which by virtue of its undiminished community influence, its tradition of orthodox learning, and its ethic of administrative service, made possible the reintegration of the traditional state in a shape to that of its predecessor. ${ }^{\prime 23}$

Dia juga menolak definisi gentry Cina yang disusun oleh Chang Chung-li dan Ho Ping-ti tentang masalah dimana garis batas harus ditarik, ${ }^{24}$ karena "neither is quite successful in relating status to the context in which it is recognized, or power to the context in which it is wielded." ${ }^{25}$ Lagipula, Kuhn berusaha untuk membedakan terminologi 'gentry' dan 'elite.' Kuhn membagi gentry ke dalam tiga kelompok, masing-masing berhubungan dengan kekuasaan dan prestis mereka pada berbagai skala organisasi: elit nasional, elit propinsial, dan elit lokal. Singkatnya, dia menggunakan istilah gentry untuk mengacu kepada para sarjana yang bergelar secara umum. Tetapi dia menambahkan, "my working analysis of the 'elite' will distinguish the scales of organization at which such person enjoyed status and wielded influence, and will also recognize that, at the local level, commoners might exercise powers that were in some cases hardly distinguishable from those of degree holders." 26 Menurut pandangan saya pribadi, ini merupakan definisi yang tepat dalam menjelaskan gentry Cina pada masa akhir kekaisaran Cina. Karena itu, definisi Kuhn ini sangat membantu untuk memahami peran gentry pada masa tersebut.

Namun, karya besar Chang Chung-li yang berjudul The Chinese Gentry, dianggap

${ }^{20}$ John K. Fairbank, China: A New History (Cambridge, Massachusetts \& London: Belknap Harvard, 1992), hal. 102

${ }^{21}$ Frederic Wakeman, The Fall of Imperial China (New York: The Free Press, 1975), pp. 19-28

${ }^{22}$ Chang Chung-li. op. cit. hal. 137

${ }^{23}$ Philip A. Kuhn, Rebellion and Its Enemies in Late Imperial China:Militarization and Social Structure, 1796-1864 (Cambridge, Massachusetts \& London: Harvard University Press, 1980), hal. 3

24 Bagi Chang Chung-li, gentry terdiri dari semua pemegang gelar akademik, dari yang terendah (shengyuan, atau sarjana distrik) sampai yang tertinggi (jin-shi, atau sarjana metropolitan). Sementara Ho Pingti menganggap sheng-yuan tidak termasuk dalam definisi gentry, karena status sosial mereka tidak dapat dibandingkan dengan yang dimiliki oleh mereka yang memiliki gelar lebih tinggi.

${ }^{25}$ Kuhn, op.cit. hal. 3-4

26 Ibid. 
sebagai karya yang sangat lengkap tentang gentry Cina, yang merupakan hasil survey atas ribuan biografi gentry yang terdapat dalam bagian biografi dari sejarah lokal, yaitu catatan-catatan dari propinsi, prefektur, dan distrik. Dalam karya klasika mengenai gentry Cina ini, Chang menggambarkan hampir semua aspek dari institusi gentry ini dan memberi penekanan pada peran-peran mereka dalam masyarakat.

Dengan diberikannya fungsi-fungsi sosial kemasyarakatan dan hak-hak istimewa kepada mereka, yang mereka jaga demikian kuatnya selama berabad-abad, kaum gentry ini diberi label sebagai konservatif, tradisionalis, dan oportunis. Namun, bagaimana menjelaskan partisipasi mereka dalam gerakan-gerakan reformasi di akhir jaman Qing? Apa motif yang menentukan yang berada di belakang tindakan mereka. Polachek dalam upayanya untuk merekonstruksi Perang Candu beranggapan bahwa kaum literati atau kelompok elit ini berperan penting dalam mendorong pemerintah kekaisaran, melalui intrik dan persuasi politik, untuk memulai perang melawan Inggris. ${ }^{27}$ Gambaran ini sama sekali berbeda dengan karya-karya sebelumnya mengenai subjek ini yang menganggap bahwa perang dipaksakan oleh Inggris kepada Cina, untuk menekan Cina membuka wilayah pedalamannya bagi perdagangan.

Ketika Cina mulai merasa dampak dari aktivitas agresif imperialisme yang dilakukan oleh Barat pada wilayah mereka beberapa saat sebelum Perang Candu, terdapat beberapa insiden menentang orang asing di beberapa lokalitas yang dikaitkan dengan xenofobia dan gerakan anti-Kristen. Gerakan-gerakan ini pada umumnya dilancarkan oleh gentry lokal. Insiden-insiden ini adalah contoh dari sebuah gerakan yang lebih besar lagi dari kaum gentry yang melibatkan gentry tingkat propinsi dan metropolitan untuk menangkis intrusi Barat terhadap kehidupan ekonomi dan politik sebagaimana yang diindikasikan oleh Polachek. ${ }^{28}$

Dalam masa akhir dinasti Qing, banyak tokoh dari kaum gentry ini yang menganjurkan dan terlibat dalam berbagai gerakan reformasi, dari Restorasi Tongzhi atau Tongzhi Zhongxin 同治中興 (1860-1874) yang melibatkan para gentry Zuo Zongtang, Li Hongzhang, dan Zeng Guofan, dan Wuxu Bianfa 戊戌變法 atau Reformasi 100 hari. (11 Juni - 21 September 1898) yang melambungkan nama-nama Kang Youwei, Liang Qichao serta Tan Sitong.

\section{PENUTUP}

Demikianlah sekelumit kisah sejarah singkat dari kaum gentry Cina. Kaum yang dikenal sebagai penjaga peradaban Cina ini mungkin secara fisik telah sirna dari kehidupan masyarakat Cina modern. Masyarakat Cina modern dewasa ini sudah jauh

\footnotetext{
${ }_{27}$ James M. Polachek, The Inner Opium War (Cambridge, Massachusetts \& London: Harvard University Press, 1992)

${ }^{28}$ Ibid., passim.
} 
meninggalkan jaman kekaisaran yang ortodoks, dan sedang mabuk dengan keberhasilan perekonomian mereka.

Namun demikian, tampaknya mereka tidak mudah meninggalkan nilai-nilai dan perilaku tradisional Konfusian, yang sejenak pernah "ditanggalkan" pada era Mao Zedong. Di bawah kemilau dan eforia keberhasilan perekonomian Cina, apabila kita dengan jeli mengamati gaya hidup dan tingkah laku masyarakat Cina modern, baik di Taiwan mau pun di RRC, maka nilai-nilai dan perilaku kaum gentry masih bisa terlihat dalam keseharian mereka. Rupanya, gaya hidup modern dan tradisional dapat hidup berdampingan secara dinamis dalam masyarakat, bahkan saling mengisi dalam membangun peradaban Cina modern.

Kaum gentry tradisional diganti oleh kaum gentry modern; para elit partai, kaum cendikiawan, orang-orang kaya, serta tokoh masyarakat dalam masyarakat Cina modern yang berperan sebagai penghubung antara kepentingan pemerintah dan rakyatnya. Tampaknya perubahan dan kesinambungan di Cina merupakan dua fenomena yang diterima secara dinamis, berjalan searah, saling melengkapi dan memperkaya, serta tidak antagonistik.

\section{BIBLIOGRAFI}

Balazs, Etienne. Chinese Civilization and Bureaucracy: Variations on a Theme.Translated by H.M. Wright and edited by Arthur F. Wright. New Haven \& London: Yale University Press. 1970.

Barbieri-Low, Anthony J. Artisans in Early Imperial China. Seattle \& London: University of Washington Press. 2007.

Chang Chung-li. The Chinese Gentry. Seattle: University of Washington Press. 1955.

Ebrey, Patricia Buckley, Anne Walthall, James Palais. The Cambridge Illustrated History of China. Cambridge: Cambridge University Press. 1999.

. East Asia: A Cultural, Social, and Political History. Boston: Houghton Mifflin Company. 2006.

Fairbank, John King and Merle Goldman. China: A New History. Second Enlarged Edition (2006). Cambridge, MA; London: The Belknap Press of Harvard University Press. 1992.

Franke, Wolfgang. The Reform and Abolition of the Traditional China Examination System. Cambridge, Massachusetts: East Asian Research Center, Harvard University. 1968.

Kuhn, Philip A. Rebellion and Its Enemies in Late Imperial China:Militarization and Social Structure, 1796-1864. Cambridge, Massachusetts \& London: Harvard University Press. 1980.

Michael, Franz. "State and Society in Nineteenth Century China," in World Politics: A Quartely Journal of International Relations (Volume 3, Number 3, April 1955). 1955.

Polachek, James M. The Inner Opium War. Cambridge, Massachusetts \& London: 
Harvard University Press. 1992.

Spence, Jonathan. The Search for Modern China; Second Edition. New York: W.W. Norton \& Company. 1999.

Wakeman, Frederic. The Fall of Imperial China. New York: The Free Press. 1975.

Yuan, Zheng. "Local Government Schools in Sung China: A Reassessment," in History of Education Quarterly (Volume 34, Number 2; Summer 1994). 1994. 